\title{
PENGEMBANGAN HANDOUT PEMBELAJARAN TEMATIK UNTUK SISWA SEKOLAH DASAR KELAS III
}

\author{
Retno Ningtyas dan Tri Nova Hasti Yunianta \\ Program Studi Pendidikan Matematika-FKIP - UKSW Salatiga \\ e-mail: $202010022 @$ student.uksw.edu \\ Wahyudi \\ Program Studi Pendidikan Guru Sekolah Dasar-FKIP - UKSW Salatiga
}

\begin{abstract}
ABSTRAK
Bahan ajar yang sering digunakan siswa di sekolah adalah Lembar Kerja Siswa (LKS) karena harganya yang ekonomis dan relatif terjangkau. Banyak sekolah yang hanya menggunakan Lembar Kerja Siswa (LKS) saja tanpa adanya handout atau buku penunjang sebagai pegangan siswa sehingga bahan ajar yang dapat digunakan anak belajar secara mandiri kurang dalam proses pembelajaran. Penelitian ini bertujuan untuk menghasilkan produk bahan ajar berupa handout pembelajaran tematik gambar seri untuk siswa sekolah dasar kelas III pada materi keliling dan luas persegi dan persegi panjang yang valid, efektif dan praktis. Penelitian ini merupakan jenis penelitian $R \& D$ (Research and Development). Penelitian ini mengacu pada model desain sistem pembelajaran ADDIE, yaitu: analysis, design, development, implementation, dan evaluation. Instrumen yang digunakan untuk memperoleh data pembuatan dan kualitas handout, yaitu: lembar penilaian handout, lembar pendapat siswa, wawancara guru, dan pretest-postest. Keberhasilan pembuatan produk ini ditinjau dari segi valid, efekif, dan praktis. Hasil penelitian menyatakan: (1) valid yang ditunjukkan dalam dua aspek yaitu (a) aspek materi yang memperoleh persentase penilaian 78,66\% menunjukkan kategori kualitatif baik (B), (b) aspek tampilan memperoleh persentase penilaian $80 \%$ menunjukkan kategori kualitatif sangat baik (SB); (2) Efektif yang dinilai berdasarkan (a) uji ketuntasan klasikal yang menunjukkan $t_{\text {hitung }}=5,148$ dengan taraf signifikan $5 \%$ dan $\mathrm{dk}=(\mathrm{n}-1)=33$ diperoleh nilai $\mathrm{t}_{\text {tabel }}=1,697$, maka $\mathrm{t}_{\text {hitung }}>$ $\mathrm{t}_{\text {tabel }}$ sehingga dapat disimpulkan rata-rata hasil belajar siswa melampaui KKM (b) persentase ketuntasan postest banyak siswa yang lulus KKM sekolah yaitu 79,412\% siswa; (3) Praktis yang ditentukan oleh (a) penilaian observer memperoleh persentase penilaian $87 \%$ menunjukkan kategori kualitatif sangat baik (SB), (b) handout memperoleh respon positif siswa dalam penggunaannya pada pembelajaran matematika. Pembelajaran dengan menggunakan produk ini menjadi lebih menyenangkan dan membuat siswa menjadi aktif. Produk ini selain berisi gambargambar yang sesuai dengan dan tema yang berkaitan dengan lingkungan rumah juga di dalam materi yang disajikan diberikan proses terbentuknya suatu rumus sehingga siswa dapat belajar secara runtut tentang rumus yang diperoleh.
\end{abstract}

Kata kunci: handout, pembelajaran tematik, gambar seri 


\section{PENDAHULUAN}

Proses pembelajaran di sekolah selain guru yang memegang peranan penting, keberadaan bahan ajar juga sangat menunjang proses pembelajaran agar terlaksana dengan baik (Prastowo, 2012). Bahan ajar yang sering digunakan siswa di sekolah adalah Lembar Kerja Siswa (LKS) karena harganya yang ekonomis dan relatif terjangkau. Banyak sekolah yang hanya menggunakan Lembar Kerja Siswa (LKS) saja tanpa adanya handout atau buku penunjang sebagai pegangan siswa sehingga bahan ajar yang dapat digunakan anak belajar secara mandiri kurang dalam proses pembelajaran. Guru-guru di Sekolah Dasar banyak mengandalkan penggunaan LKS dalam pembelajaran matematika yang penyusunannya pun masih abstrak terutama untuk anak usia Sekolah Dasar kelas III sehingga kurang efektif dalam pembelajaran matematika. Berdasarkan hal tersebut dalam penelitian ini akan menghasilkan bahan ajar yang dapat digunakan sebagai pegangan siswa, bahan ajar yang dipilih adalah handout.

Handout merupakan salah satu bahan ajar yang sangat ringkas. Handout bersumber dari beberapa literatur yang relevan terhadap kompetensi dasar dan materi pokok yang diajarkan serta dapat memudahkan siswa dalam mengikuti proses pembelajaran (Prastowo, 2012). Penggunaan handout sebagai salah satu bahan ajar yang digunakan guru memberikan dampak cukup besar bagi siswa dalam memahami materi yang diberikan oleh guru apalagi jika handout tersebut dibuat oleh guru itu sendiri karena sesuai dengan kondisi siswa di dalam kelas. Hal tersebut karena handout merupakan salah satu bahan ajar yang dapat dimanfaatkan dalam pembelajaran (Setiawan, 2007). Raharjo (2011) menyatakan fungsi handout adalah sebagai alat bantu sehingga siswa lebih memahami materi yang diajarkan.

Berdasarkan hasil wawancara dengan Ibu Ike Damayanti di SD Negeri Kutowinangun 07 pada tanggal 13 Januari 2014 dapat disimpulkan bahwa siswa sebenarnya lebih menyukai adanya bahan ajar dalam pembelajaran yang bergambar dibandingkan Lembar Kerja Siswa (LKS) karena hanya berisikan latihan-latihan saja tanpa adanya kegiatan-kegiatan yang dapat menunjang proses pembelajaran di dalam kelas. Guru mereka hanya memberikan penjelasan sebentar, kemudian siswa diminta untuk mengerjakan soal-soal di Lembar Kerja Siswa (LKS) dan diminta mencocokkan jawaban dengan temannya. LKS yang digunakan sebagai pegangan utama siswa berisikan pemberian rumus langsung tanpa adanya proses yang menghasilkan rumus-rumus tersebut sehingga diperlukan bahan ajar yang dapat membantu siswa untuk lebih memahami materi yang diajarkan. 
Siswa cenderung menyukai bahan ajar yang berisikan contoh-contoh langsung dalam kehidupan nyata sehingga mereka dapat lebih paham dengan apa yang sedang mereka pelajari.

Salah satu alternatif bahan ajar yang dapat digunakan untuk menambah pengetahuan dan pegangan siswa adalah handout pembelajaran tematik. Pembelajaran tematik adalah pembelajaran yang menggunakan tema dalam menyatukan beberapa mata pelajaran sehingga diharapakan dapat memberikan pengalaman yang bermakna pada siswa. Model pembelajaran tematik melibatkan beberapa mata pelajaran menjadi satu tema dan menggunakan konsep-konsep yang sudah diperoleh peserta didik melalui pengalaman langsung serta menghubungkannya dengan konsep lain yang telah dipahaminya. Pembelajaran tematik berfokus pada pada tahapan yang harus ditempuh siswa dalam memahami materi yang disampaikan serta proses pengembangannya dalam keterampilan (Musclich, 2011).

Handout yang akan dikembangkan dalam penelitian ini adalah handout yang mempunyai ciri khusus berseri dan bergambar yang membedakan dengan handout yang ada selama ini. Media gambar merupakan media yang paling umum dipakai dalam media pendidikan serta dapat dimengerti dan dinikmati dimana-mana (Sadiman, 2011). Gambar seri merupakan media grafis yang digunakan untuk menerangkan suatu rangkaian perkembangan. Setiap seri media gambar bersambung dan selalu terdiri atas sejumlah gambar (Rohani, 1997).

Handout Pembelajaran Tematik Gambar Seri merupakan handout yang disusun dengan menerapkan model pembelajaran tematik serta gambar yang alur ceritanya saling berurutan (gambar seri). Pemberian gambar pada handout bertujuan agar siswa lebih mudah memahami materi yang disampaikan serta dapat membuat siswa tertarik dengan materi yang diajarkan. Proses pemberian materi di dalam handout ini disusun berdasarkan proses sehingga siswa dapat mengetahui proses menghasilkan rumus tersebut, hal ini yang membedakan dengan bahan ajar yang digunakan siswa selama ini yang berisikan pemberian rumus langsung tanpa adanya proses.

Fitriani (2013) menemukan bahwa pembelajaran dengan menggunakan media gambar seri menunjukkan hasil yang positif dari siswa. Izzati (2013) menemukan bahwa pembelajaran dengan menggunakan bahan ajar tematik mendapatkan hasil yang positif dan dapat meningkatkan aktivitas siswa. Tujuan penelitian ini adalah untuk mengetahui kevalidan, keefektifan dan kepraktisan handout pembelajaran tematik gambar seri. 


\section{METODOLOGI PENELITIAN}

Penelitian ini merupakan jenis penelitian R\&D adalah metode penelitian yang untuk menghasilkan produk tertentu, dan menguji keefektifan produk tersebut (Sugiyono, 2010). Produk yang akan dihasilkan dalam penelitian ini berupa handout pembelajaran tematik gambar seri pada materi keliling dan luas persegi dan persegi panjang untuk siswa SD kelas III. Subjek yang dalam penelitian ini adalah guru dan siswa kelas III SDN Kutowinangun 07 Salatiga.

Model desain sistem pembelajaran untuk menghasilkan handout pembelajaran yang digunakan dalam penelitian ini adalah model ADDIE. Model ini sesuai dengan namanya, terdiri dari lima fase atau tahap utama, yaitu Analysis, Design, Development, Implementation, dan Evaluation (Pribadi, 2012).

Data dikumpulkan berdasarkan lembar penilaian handout dan tes. Lembar penilaian handout terdiri dari lembar kevalidan dan kepraktisan handout. Tes dilakukan untuk mengetahui keefektifan penggunaan handout dalam proses pembelajaran.

\section{HASIL PENELITIAN}

Berdasarkan penelitian yang dilakukan, diperoleh handout pembelajaran tematik gambar seri dengan menggunakan model desain sistem pembelajaran $A D D I E$ yang terdiri dari lima tahap.
Tahap analysis, pada tahap ini dilakukan analisis kurikulum, materi dan situasi. Pada analisis kurikulum dan materi dipilih kompetensi dasar menghitung keliling dan luas persegi dan persegi panjang. Pada analisis situasi berdasarkan hasil wawancara dengan guru ditemukan masalah pembelajaran matematika masih terbaatas pada: (1) peran aktif siswa yang belum maksimal; (2) ketergantungan siswa terhadap guru dalam memahami materi matematika, (3) belum ada bahan ajar matematika untuk siswa yang menarik dan menyenangkan. Salah satu solusi yang dapat dipertimbangkan dengan menggunakan handout pembelajaran

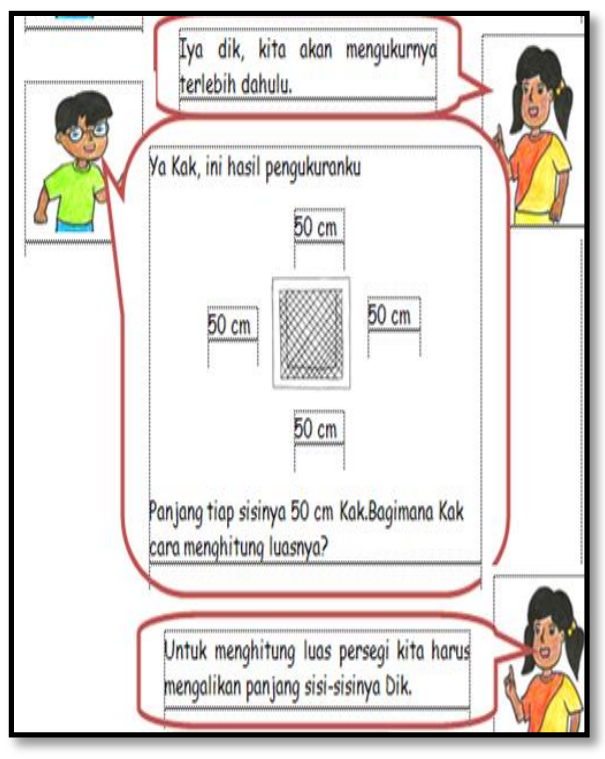

tematik gambar seri sebagai tambahan (suplemen) bahan ajar siswa dalam mempelajari matematika disamping penggunaan LKS (Lembar Kerja Siswa). 
Tahap design, pada tahap ini dilakukan beberapa hal yaitu: (1) mengumpulkan referensi materi; (2) menyusun kerangkan handout; (3) merancang pembelajaran sesuai tujuan handout; (4) menyusun handout sesuai kerangka dan alur pembelajaran; (5) melengkapi unsur-unsur handout sesuai kerangka; (6) merancang tampilan/ layout handout matematika.

Tahap development, pada tahap ini dilakukan pembuatan handout awal, valiadasi ahli dan revisi handout sebelum akhirnya diimplementasikan ke siswa. Pembuatan handout awal meliputi: (1) berbentuk media cetak;
(2) komponen-komponen dalam handout pembelajaran tematik gambar seri. Revisi handout berdasarkan masukan para ahli meliputi tampilan handout, overview materi, tata tulis penggunaan EYD, penggunaan kalimat yang efektif dan perbaikan beberapa soal dalam latihan soal. Berikut overview materi pada pembuatan handout tahap awal.

Saran dan kritik juga diberikan validator sampai handout dapat diimplementasikan. Berikut daftar saran dan kritik serta tindak lanjut.

\begin{tabular}{|l|l|}
\hline \multicolumn{1}{|c|}{ Saran dan Kritik } & \multicolumn{1}{c|}{ Tindak Lanjut } \\
\hline $\begin{array}{l}\text { Gambar } \text { cover } \text { atau sampul } \\
\text { sebaiknya lebih diperjelas. }\end{array}$ & $\begin{array}{l}\text { Gambar cover atau sampul lebih } \\
\text { diperjelas dalam proses } \\
\text { pembuatannya. }\end{array}$ \\
\hline $\begin{array}{l}\text { Judul lebih dibuat simpel } \\
\text { dengan judul "Lingkungan } \\
\text { Rumahku". }\end{array}$ & $\begin{array}{l}\text { Mengganti judul "Lingkungan Rumah } \\
\text { dan Sekitarnya" dengan judul } \\
\text { "Lingkungan Rumah". }\end{array}$ \\
\hline $\begin{array}{l}\text { Perbaiki pemilihan kata pada } \\
\text { halaman tertentu, masih ada } \\
\text { penggunaan kata "kau". }\end{array}$ & $\begin{array}{l}\text { Memperbaiki penggunaan kata "kau" } \\
\text { pada halaman 7 dan 8. }\end{array}$ \\
\hline $\begin{array}{l}\text { Perbaiki beberapa gambar } \\
\text { yang terlihat tidak } \\
\text { proporsional (gambar terlihat } \\
\text { gemuk). }\end{array}$ & $\begin{array}{l}\text { Memperbaiki letak beberapa gambar } \\
\text { yang tidak proporsional. }\end{array}$ \\
\hline $\begin{array}{l}\text { Tata tulis penggunaan EYD } \\
\text { masih banyak yang perlu } \\
\text { disempurnakan. }\end{array}$ & $\begin{array}{l}\text { Memperbaiki beberapa kalimat yang } \\
\text { penulisannya tidak sesuai dengan } \\
\text { EYD. }\end{array}$ \\
\hline \multicolumn{1}{|c|}{ Saran dan Kritik } & \multicolumn{1}{|c|}{ Tindak Lanjut } \\
\hline $\begin{array}{l}\text { Penggunaan rumus keliling } \\
\text { dan luas persegi dan persegi } \\
\text { panjang tidak ditemukan, } \\
\text { masih diberikan. Munculkan }\end{array}$ & $\begin{array}{l}\text { Memperbaiki penanaman konsep } \\
\text { keliling dan luas persegi dan persegi } \\
\text { panjang dengan menggunakan } \\
\text { ilustrasi, serta merancang alur }\end{array}$ \\
\hline
\end{tabular}




\begin{tabular}{|l|l|}
\hline $\begin{array}{l}\text { penanaman konsep keliling } \\
\text { dan luas oleh tokoh cerita }\end{array}$ & $\begin{array}{l}\text { penemuan rumus keliling dan luas } \\
\text { persegi dan persegi panjang dengan } \\
\text { melibatkan percakapan antar tokoh. }\end{array}$ \\
\hline $\begin{array}{l}\text { Pergunakan kalimat yang } \\
\text { efektif, bahasa resmi dan } \\
\text { perhatikan tanda baca. }\end{array}$ & $\begin{array}{l}\text { Memperbaiki penggunaan kalimat } \\
\text { yang tidak efektif serta } \\
\text { memperbaikinya dengan bahasa } \\
\text { resmi, memperbaiki tanda baca di } \\
\text { dalam penggunaan kalimat. }\end{array}$ \\
\hline $\begin{array}{l}\text { Penggunaan gambar yang } \\
\text { tidak efektif sebaiknya } \\
\text { dikurangi. }\end{array}$ & $\begin{array}{l}\text { Mengurangi penggunaan gambar yang } \\
\text { tidak efektif di dalam handout. }\end{array}$ \\
\hline $\begin{array}{l}\text { Perbaiki beberapa soal dalam } \\
\text { cek pemahaman yang kurang } \\
\text { jelas sehingga bisa } \\
\text { dikerjakan. }\end{array}$ & $\begin{array}{l}\text { Memperbaiki beberapa soal dalam } \\
\text { cek pemahaman agar lebih jelas } \\
\text { sehingga dapat dikerjakan. }\end{array}$ \\
\hline
\end{tabular}

Handout yang sudah divalivalidator. Berikut beberapa revisi dasi selanjutnya direvisi sesuai saran sesuai saran validator.

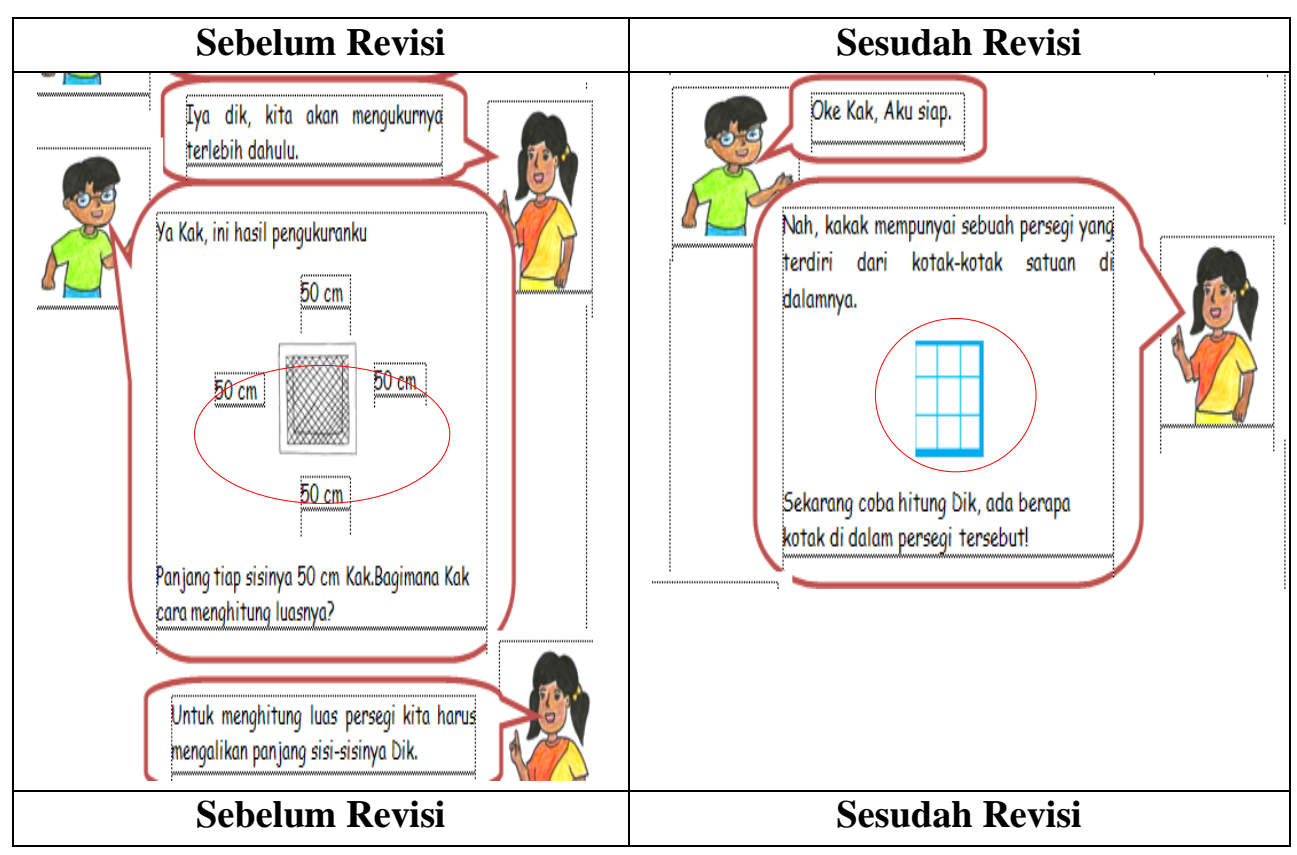




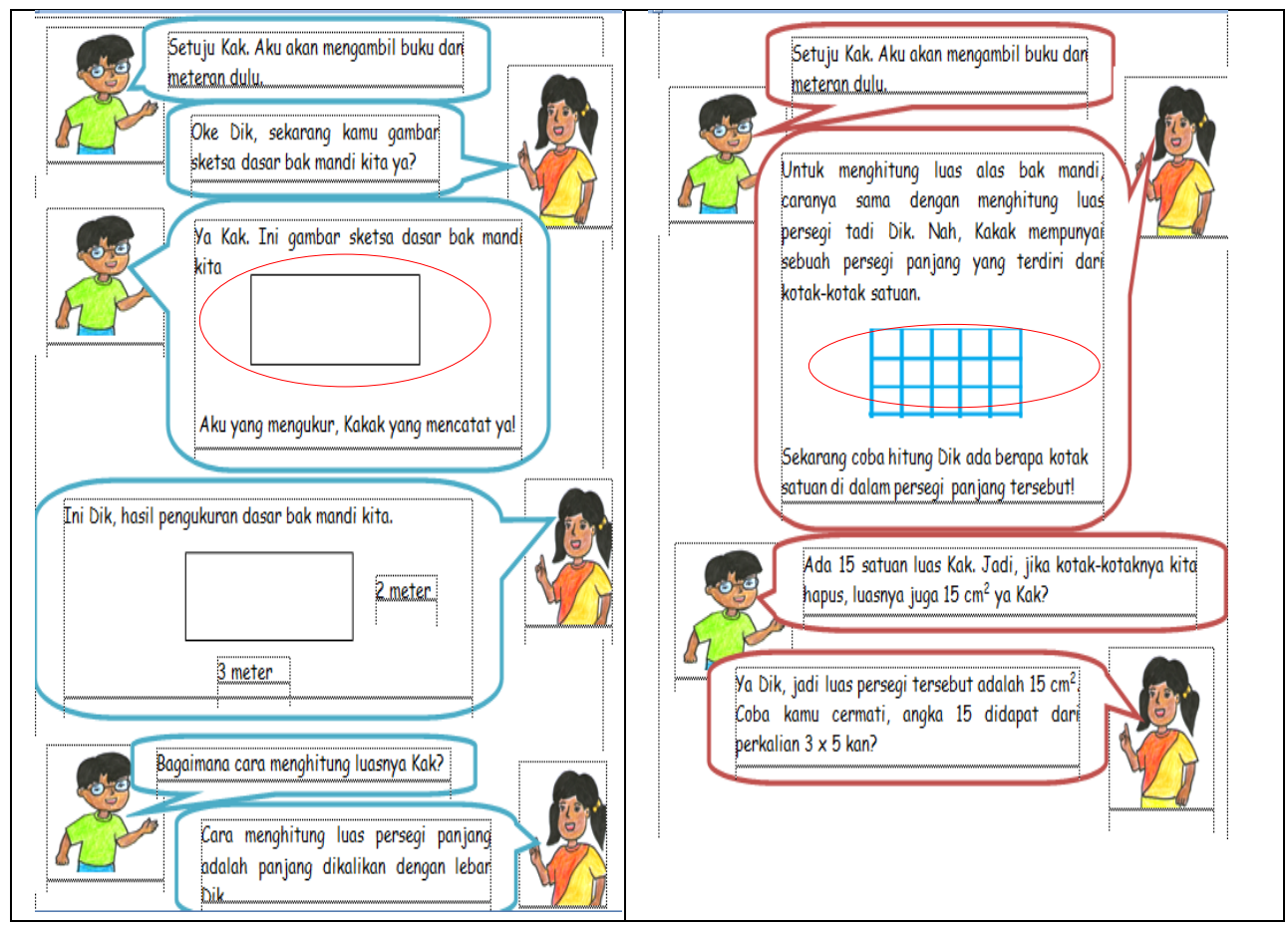

Tahap implementation, pada tahap ini dilakukan proses penerapan handout akhir berdasarkan hasil beberapa kali revisi yang sudah disetujui oleh para validator. Implementasi handout ini dilaksanakan dalam enam kali pertemuan. Pada awal proses implementasi ini siswa belum terbiasa dengan bahan ajar yang baru, siswa masih kesulitan dalam memahami alur handout akan tetapi pada pertemuan selanjutnya siswa sudah paham dan aktif dalam proses pembelajaran.

Tahap evaluation, pada tahap ini dilakukan evaluasi penggunaan handout yang telah disusun dan diujicobakan. Hasil evaluasi handout terdiri dari analisis kevalidan, keefektifan dan kepraktisan. Berdasarkan analisis data kevalidan ang terdiri dari aspek materi dan aspek tampilan, pada aspek materi diperoleh skor rata-rata adalah 59 dengan persentase 78,66\% menunjukkan kategori baik sedangkan pada aspek tampilan diperoleh skor rata-rata adalah 36 dengan persentase $80 \%$ menunjukkan kategori sangat baik sehingga dapat disimpulkan handout yang dikembangkan dapat disimpulkan valid. Analisis data keefektifan terdiri dari uji ketuntasan klasikal dan persentase ketuntasan siswa pada posttest. Berdasarkan uji ketuntasan klasikal diperoleh nilai $\mathrm{t}_{\text {hitung }}$ $=5,134$. Taraf signifikan $5 \%$ dan $\mathrm{dk}$ $=(\mathrm{n}-1)=33$ diperoleh nilai $\mathrm{t}_{\text {tabel }}=1$, 697, maka $t_{\text {hitung }}>\mathrm{t}_{\text {tabel }}$, berarti $\mathrm{H}_{0}$ ditolak, hal ini berarti juga bahwa ratarata hasil belajar siswa melampaui 
KKM. Persentase ketuntasan posttest siswa diperoleh $79,412 \%$ menunjukkan keefektifan hasil belajar tinggi atau dapat dikatakan handout efektif untuk pembelajaran matematika. Analisis data kepraktisan yang terdiri dari penilaian observer dan respon siswa. Berdasarkan penilaian observer diperoleh skor rata-rata 43,5 dengan persentase $87 \%$ menunjukkan kategori sangat baik. Respon siswa terhadap handout yang dihasilkan berdasarkan lembar pendapat siswa secara keseluruhan memperoleh respon positif, dapat disimpulkan handout praktis.

\section{PEMBAHASAN}

Handout yang baik adalah handout yang dapat digunakan sebagai pendamping bahan ajar yang digunakan guru, ditulis dengan menggunakan bahasa yang baik dan mudah dimengerti, disajikan secara menarik bila perlu dilengkapi dengan gambar, isi handout juga dapat membantu mengaktifkan siswa dalam proses pembelajaran. Revisi pada handout meliputi revisi materi, penulisan kata,tata tulis, penggunaan kalimat efektif, tanda baca dan gambar sesuai dengan tujuan penelitian yaitu handout pembelajaran tematik gambar seri.

Revisi handout terkait dengan aspek materi. Pada revisi ini dimulai dengan perubahan handout yang semula terlihat kaku dan masih terlihat seperti LKS pada umumnya. Handout kemudian dirubah sesuai dengan saran validator yaitu dibuat overview materi yang tidak diberikan rumus secara langsung seperti bahan ajar pada umumnya dengan harapan anak dapat menemukan rumus keliling dan luas persegi dan persegi panjang secara mandiri sesuai dengan alur cerita. Pada alur cerita dalam setiap gambar direvisi dengan penggabungan beberapa mata pelajaran sesuai dengan konsep pembelajaran tematik serta diberikan sisipan pendidikan karakter pada siswa. Perubahan kegiatan belajar yang direncanakan semula hanya 4 kegiatan belajar dirubah menjadi 6 kegiatan belajar karena siswa akan kesulitan jika materi antara keliling atau luas persegi dan persegi panjang dimasukkan menjadi 1 kegiatan belajar. Kegiatan belajar disusun menjadi 2 macam yaitu kegiatan belajar kelompok dan mandiri dengan harapan siswa lebih antusias mengikuti proses pembelajaran. Revisi perbaikan pemilihan kata dan penggunaan kalimat yang efektif juga dilakukan dalam pembuatan handout karena kalimat yang kurang efektif akan membuat siswa bingung dalam memahami alur cerita di dalam handout. Berdasarkan hasil beberapa kali revisi materi sehingga diperoleh hasil penilaian pada aspek materi dengan skor rata-rata adalah 59 dengan persentase $78,66 \%$ dan termasuk kategori baik.

Revisi handout terkait dengan aspek tampilan. Pada revisi pada aspek ini dimulai dengan perubahan judul 
tampilan handout yang semula "lingkungan rumah dan sekitarnya" dipersingkat menjadi" lingkungan rumah". Layout sampul depan juga diperbaiki agar terlihat lebih jelas. Perbaikan gambar juga dilakukan pada gambar yang terlihat tidak proposional (terlihat gemuk). Pengurangan gambar yang tidak memiliki fungsi juga dilakukan agar tampilan handout lebih efektif. Berdasarkan hasil beberapa kali revisi tampilan sehingga diperoleh hasil penilaian pada aspek tampilan dengan skor rata-rata adalah 36 dengan persentase $80 \%$ dan termasuk kategori sangat baik. Secara keseluruhan berdasarkan aspek materi dan tampilan handout pembelajaran tematik gambar seri valid.

Berdasarkan hasil uji ketuntasan klasikal dapat dinyatakan bahwa handout pembelajaran tematik gambar seri efektif, hal tersebut dibuktikan dengan perhitungan yang memperoleh nilai $\mathrm{t}_{\text {hitung }}=5,134$. Taraf signifikan $5 \%$ dan $\mathrm{dk}=(\mathrm{n}-1)=33$ diperoleh nilai $\mathrm{t}_{\text {tabel }}=1,697$, maka $\mathrm{t}_{\text {hitung }}>\mathrm{t}_{\text {tabel }}$, berarti $\mathrm{H}_{0}$ ditolak, hal ini berarti juga bahwa rata-rata hasil belajar pada siswa dalam kelas uji coba produk melampaui KKM. Hal ini menunjukkan bahwa terjadi keberhasilan penggunaan handout pembelajaran tematik gambar seri di dalam pembelajaran matematika untuk siswa Sekolah Dasar kelas III pada materi keliling dan luas persegi dan persegi panjang. Keberhasilan penggunaan produk ini di dalam proses pembelajaran karena dapat menarik minat belajar siswa dalam mempelajari matematika khususnya dalam materi keliling persegi dan persegi panjang. Produk ini selain terdiri dari gambargambar yang berwarna-warni, juga terdiri dari alur cerita yang mudah dipahami oleh anak-anak usia Sekolah Dasar kelas III. Tema dan tokoh-tokoh yang digunakan juga dekat dengan keseharian siswa berupa lingkungan rumah serta kegiatan-kegiatan yang dilakukan di dalam rumah dapat memberikan pemahaman lebih mendalam pada siswa.

Materi di dalam handout ini juga disusun sesuai dengan pembelajaran tematik yaitu mengaitkan beberapa matapelajaran menjadi satu di dalam sebuah bahan ajar, mata pelajaran yang dikaitkan adalah Bahasa Indonesia, Pendidikan Kewarganegaraan, Ilmu Pengetahuan Alam, dan Ilmu Pengetahuan Sosial. Handout pembelajaran tematik gambar seri ini juga dapat membantu guru menanamkan karakterkarakter yang diharapkan dapat tertanam di dalam diri siswa. Karakter yang ingin ditanamkan kepada siswa melalui handout ini adalah rasa percaya diri, mandiri, kerjasama, cinta lingkungan, kebersihan, dan patuh kepada orangtua. Kegiatan-kegiatan belajar di dalam handout ini juga disusun dengan mengaplikasikan beberapa model pembelajaran kooperatif. Model pembelajaran kooperatif yang digunakan adalah Numbered Heads Together dan 
Talking Stick. Kegiatan belajar dengan mengaplikasikan beberapa model pembelajaran tersebut dapat membuat mereka antusias dalam mengikuti proses pembelajaran. Pada bagian refleksi diri bermanfaat untuk meringkas materi yang sudah dipelajari siswa. Handout pembelajaran tematik gambar seri dapat digunakan sebagai suplemen bahan ajar yang digunakan dalam pembelajaran matematika karena telah efektif dalam proses uji coba penggunaannya.

Persentase ketuntasan 79,412\% menunjukkan keefektifan hasil belajar tinggi. Sebanyak 27 siswa tuntas serta 7 siswa tidak tuntas dalam posttest. Jumlah ini meningkat dibandingkan pada saat melihat kondisi awal yaitu dengan pemberian pretest yang hanya 16 siswa tuntas. Hal ini membuktikan bahwa pada saat kondisi awal kemudian diberikan perlakuan dengan handout pembelajaran tematik gambar seri menjadikan peningkatan pemahaman siswa. Pengaruh dari kondisi awal kemudian dilakukan posttest untuk mengukur hasil belajar dan mengalami peningkatan menunjukkan bahwa handout pembelajaran tematik gambar seri efektif digunakan dalam proses pembelajaran.

Berdasarkan penilaian observer diperoleh skor rata-rata 43,5 dengan persentase $87 \%$ dan menunjukkan kategori sangat baik. Hal ini karena guru dapat menerapkan handout dengan baik dalam proses pembelajaran. Guru memberikan siswa kesempatan untuk aktif dalam proses pembelajaran serta dapat mengelola kelas dengan baik dalam kegiatan kelompok maupun mandiri. Handout juga dinilai oleh observer sudah baik dan pembelajaran tematik sudah tercermin di dalam handout. Kegiatan kelompok dan individu dapat terlaksana dengan baik serta memberikan hal baru pada siswa yang sebelumnya belum pernah dalam proses pembelajaran menggunakan model-model pembelajaran kooperatif. Observer mengatakan bahwa handout yang dibuat dapat membantu siswa dalam memahami materi, gambar yang berwarna-warni yang membuat siswa lebih senang mempelajarinya, dan dapat membuat siswa lebih antusias dalam proses pembelajaran.

Dari hasil lembar pendapat siswa menunjukkan bahwa handout mempunyai tampilan yang menarik dan menarik minat belajar matematika. Handout juga mudah dipahami dalam penggunaannya serta siswa juga berharap dapat disusun handout pembelajaran tematik gambar seri untuk materi selanjutnya. Secara umum dapat disimpulkan bahwa respon siswa positif.

Berdasarkan observasi penelitan penggunaan handout pembelajaran tematik gambar seri yang telah dilakukan peneliti mendapatkan beberapa hal yang dapat dijadikan temuan penelitian antara lain: (1) 
beberapa siswa pada saat pembagian kelompok tidak mau bergabung dengan temannya akhirnya dapat bekerja sama menyelesaikan kegiatan yang ada di dalam handout; (2) respon siswa terhadap model pembelajaran yang diterapkan sangat antusias karena sebelumnya siswa belum mendapatkan model pembelajaran yang diterapkan di dalam handout; (3) siswa menyukai tampilan dan gambar yang ada di dalam handout pembelajaran tematik gambar seri yang berwarna-warni karena sebelumnya mereka hanya menggunakan bahan ajar berupa LKS yang hanya berupa latihan soal dengan kertas buram; (4) siswa dapat memahami rumus keliling dan luas persegi dan persegi panjang melalui proses penemuan alur cerita sehingga siswa tidak diberi rumus secara langsung.

\section{SIMPULAN}

Berdasarkan hasil penelitian dan pembahasan yang telah diuraikan sebelumnya maka diperoleh beberapa kesimpulan sebagai berikut: (1) produk berupa Handout Pembelajaran Tematik Gambar Seri yang dihasilkan dalam penelitian berdasarkan penilaian validator pada aspek materi diperoleh skor rata-rata adalah 59 dengan persentase $78,66 \%$ menunjukkan kategori baik. Aspek tampilan diperoleh dengan skor rata-rata adalah
36 dengan persentase $80 \%$, menunjukkan kategori sangat baik, sehingga dapat disimpulkan handout yang dikembangkan valid;

Keefektifan pembelajaran matematika pada materi keliling dan luas persegi dan persegi panjang dengan menggunakan Handout Pembelajaran Tematik Gambar Seri memenuhi 2 indikator efektif, yaitu: Handout Pembelajaran Tematik Gambar Seri berdasarkan hasil perhitungan uji ketuntasan klasikal diperoleh nilai $\mathrm{t}_{\text {hitung }}$ $=5,134$. Taraf signifikan $5 \%$ dan $\mathrm{dk}$ $=(\mathrm{n}-1)=33$ diperoleh nilai $\mathrm{t}_{\text {tabel }}=1$, 697, maka $t_{\text {hitung }}>\mathrm{t}_{\text {tabel }}$, berarti $\mathrm{H}_{0}$ ditolak, hal ini berarti juga bahwa ratarata hasil belajar siswa melampaui KKM dan menunjukkan handout efektif digunakan dalam proses pembelajaran. Persentase ketuntasan $79,412 \%$ menunjukkan keefektifan hasil belajar tinggi atau dapat dikatakan handout efektif untuk pembelajaran matematika. (3) Kepraktisan penggunaan Handout Pembelajaran Tematik Gambar Seri di dalam proses pembelajaran berdasarkan penilaian observer diperoleh skor rata-rata 43,5 dengan persentase $87 \%$, menunjukkan kategori sangat baik. Respon siswa juga positif di dalam penggunaan handout dalam proses pembelajaran matematika, secara keseluruhan handout praktis dalam penggunaannya untuk pembelajaran matematika. 


\section{DAFTAR PUSTAKA}

Fitriani, Dian. 2012. Peningkatan Keterampilan Bercerita dengan Media Gambar Seri pada Siswa Kelas VII Mts Padureso.ejournal.umpwr.ac.id. Diunduh 16 Januari 2014. Pukul 08.50.

Izzati, N. 2013. Pengembangan Modul Tematik dan Inovatif Berkarakter pada Tema Pencemaran Lingkungan untuk Siswa Kelas VII SMP. http://journal.unnes.ac.id/vol 2 No 2 (2013). Diunduh 12 Januari 2014. Pukul 09.15

Musclich, Mansur. 2011. KTSP Pembelajaran Berbasis Kompetensi dan Kontekstual. Jakarta: Bumi Aksara

Prastowo, Andi. 2012. Panduan Kreatif Membuat Bahan Ajar. Yogyakarta: Diva Press

Pribadi, Benny A. 2011. Model Desain Sistem Pembelajaran. Jakarta: Dian Rakyat

Raharjo. 2011. Pengembangan Bahan Ajar Handout Sistem Penerima TV di SMK Piri 1 Yogyakarta. http://eprints.uny.ac.id/10269/. Diunduh 10 Januari 2014. Pukul 10.25.

Rohani, Ahmad. 1997. Media Intruksional Edukatif. Jakarta: Rineka Cipta

Sadiman, Arief S dkk. 2008. Media Pendidikan. Jakarta: PT Raja Grafindo Persada

Setiawan, Denny. 2007 . Pengembangan Bahan Ajar. Jakarta: Universitas Terbuka

Sugiyono. 2010. Metode Penelitian Pendidikan (Pendekatan Kuantitatif, Kualitatif, dan $R \& D$ ). Bandung: Alfabeta 